\title{
Tuberous sclerosis with pulmonary lymphangioleiomyomatosis and renal angiomyolipomas. Computed tomographic findings: a case
} report

Flávia G Vianna, Edson Marchiori*, Gláucia Zanetti, Claudia M Mano Branca Sarcinelli-Luz, Juliana F Carvalho, Carla Assed, Isabella G Santos Alair ASMD Santos and Alberto D Vianna

Address: Department of Radiology, Faculty of Medicine, Fluminense Federal University, Rio de Janeiro, Brazil Email: Flávia G Vianna - flavinhavianna@yahoo.com.br; Edson Marchiori* - edmarchiori@gmail.com; Gláucia Zanetti - glauciazanetti@gmail.com; Claudia M Mano - cacaumano@gmail.com; Branca Sarcinel__uz. vncaluz@gmail.com; Juliana F Carvalho - fc.juliana@gmail.com; Carla Assed - carlassed@yahoo.com.br; Isabella G Santos_abella_gu_ s\$@yahoo.com.br; Alair ASMD Santos - alair@microlink.com.br; Alberto D Vianna - albertodvianna@terra.com.br

* Corresponding author

This article is available from: http://www.casesjournal.com/content/2/I/9124

(c) 2009 Vianna et al; licensee BioMed Central Ltd.

This is an Open Access article distributed under the terms of the Creative 0 mons ttribution License (http://creativecommons.org/licenses/by/2.0), which permits unrestricted use, distribution, and reproduction in any icdium, $\mathrm{f}$ ide $\mathrm{J}$ the original work is properly cited.

\begin{abstract}
The authors describe a case ot a $\mathrm{s} I$-year- d female with tuberous sclerosis, a genetic, rare, variably expressed disease. Clinic symptoms were chest pain, and progressive dyspnea. Computed tomography scan of the hest showed bilateral, diffuse, small thin-walled cysts scattered throughout the lu rs charanceristic for pulmonary lymphangioleiomyomatosis. Computed tomography scan of tir. domen revealed enlarged, heterogeneous kidneys, with low density tumors corre ondin renal angir nyol omas ire some presentations of tuberous sclerosis and the coexistence of both conditirns cau devastating morbidity and mortality.
\end{abstract}

Received: 14 ary 200s

Accepted: I L ecur 2009

\section{Introdu or}

Tuberniss sc. osis (TS) is an autosomal dominant disorder che acteris d by the formation of hamartomatous les altiple organs, with a birth incidence of aroun ane in 10,000 [1]. However, with more sensitive screening the prevalence may be as high as one in 6,000 $[2,3]$. The disease results from mutations in one of two genes, TSC1 (encoding hamartin) or TSC2 (encoding tuberin), which have an important role in the regulation of cell proliferation and differentiation [4]. Facial angiofibromas, renal angiomyolipomas, and pulmonary lymphangiomyomatosis (LAM) are some of the major features of this disease [4]. Diagnosis is usually estab- lished on the basis of physical examination, radiological findings or both, and the presentation of the disease varies substantially. We report a case of a female patient with TS presenting with pulmonary lymphangiomyomatosis and bilateral renal angiomyolipomas.

\section{Case presentation}

A 31-year-old Caucasian Brazilian woman was admitted to the hospital with a 6-month history of chest pain and progressive dyspnea on exertion. She had angiofibromas on the malar regions of the face, which were present since her childhood. During her pregnancy, 11 years ago, she was diagnosed with polycystic kidney disease associated 
with tuberous sclerosis. She had repetitive urinary tract infections, which resulted in progressive loss of renal function. Both her grandfather and child had polycystic kidneys, and her son also presented seizures. The patient also had a history of hemorrhoidal disease causing intermittent bleeding.

On examination, the patient appeared pale, and her vital signs included a blood pressure of $120 / 80 \mathrm{mmHg}$ and a heart rate of $110 \mathrm{bpm}$. Auscultation revealed the presence of fine crackles in both lungs, and a loud systolic heart murmur was heard on the precordium. Her abdomen was tense and painful to palpation, but there were no signs of peritoneal irritation. There was a palpable mass occupying the upper abdomen and both flanks; Traube's space was obliterated. Laboratory evaluation revealed a red blood cell (RBC) count of $2.81 \times 10^{6} / \mathrm{mm}^{3}$, hemoglobin level of $9.0 \mathrm{~g} / \mathrm{dL}$, hematocrit of $27 \%$ and platelet count of $130 \times$ $10^{3} / \mathrm{mm}^{3}$. Her WBC count was normal. Serum creatinine was $3.3 \mathrm{mg} / \mathrm{dL}$; urea, $87 \mathrm{mg} / \mathrm{dL}$; glucose, $85 \mathrm{mg} / \mathrm{dL}$; sodium, $135 \mathrm{mEq} / \mathrm{L}$; potassium, $4.2 \mathrm{mEq} / \mathrm{L}$; uric acid 4.5 $\mathrm{mg} / \mathrm{dL}$; albumin, $2.8 \mathrm{~g} / \mathrm{dL}$; calcium, $7.9 \mathrm{mg} / \mathrm{dL}$; phosphorus, $5.2 \mathrm{mg} / \mathrm{dL}$; and magnesium, $2.4 \mathrm{mg} / \mathrm{dL}$.

Chest computed tomography (CT) revealed cystic formations throughout the lungs, consistent with lymphangioleiomyomatosis (Figure 1), and the presence or a pericardial effusion. The echocardiogram showed a $a$. pericardial effusion, and moderate left ventricylar hyp trophy, and a normal systolic function. An ab a inal Cl scan demonstrated enlarged, heterogeneov kidne, with multiple fat-density formations (negati ve densities, ranging from -15 to -148 Hounsfield $\mathrm{u}$ ts), wh ch corresponded to angiomyolipomas (Figui o). Julmonary function tests showed a severe ob ictive pulmonary disorder with reduced forced vital ap $\mu$, , and a positive response to bronchodila She tarted treatment with medroxyprogesterone anc her respiratory status remained stable. An ec ardiogram performed three years later reve a worse ang of cardiac condition, enlargement of igh vities and left atrium, and thickening of the ortic valve caflets; systolic function was preserved. $\%$ or up CT scans did not show significant chanom

Dis<smiles>C1C[AsH2]C1</smiles>

The bo non-invasive lesions of tuberous sclerosis can appear in any organ like the brain, heart, skin, eyes, kidney, lung, and liver. Therefore, TS has a wide clinical spectrum. The diagnosis of definitive TS is based on specific clinical features and requires the presence of two major criteria, or one major and two minor [3]. Pulmonary lymphangioleiomyomatosis, renal angiomyolipoma and facial angiofibroma are some of the major clinical features.

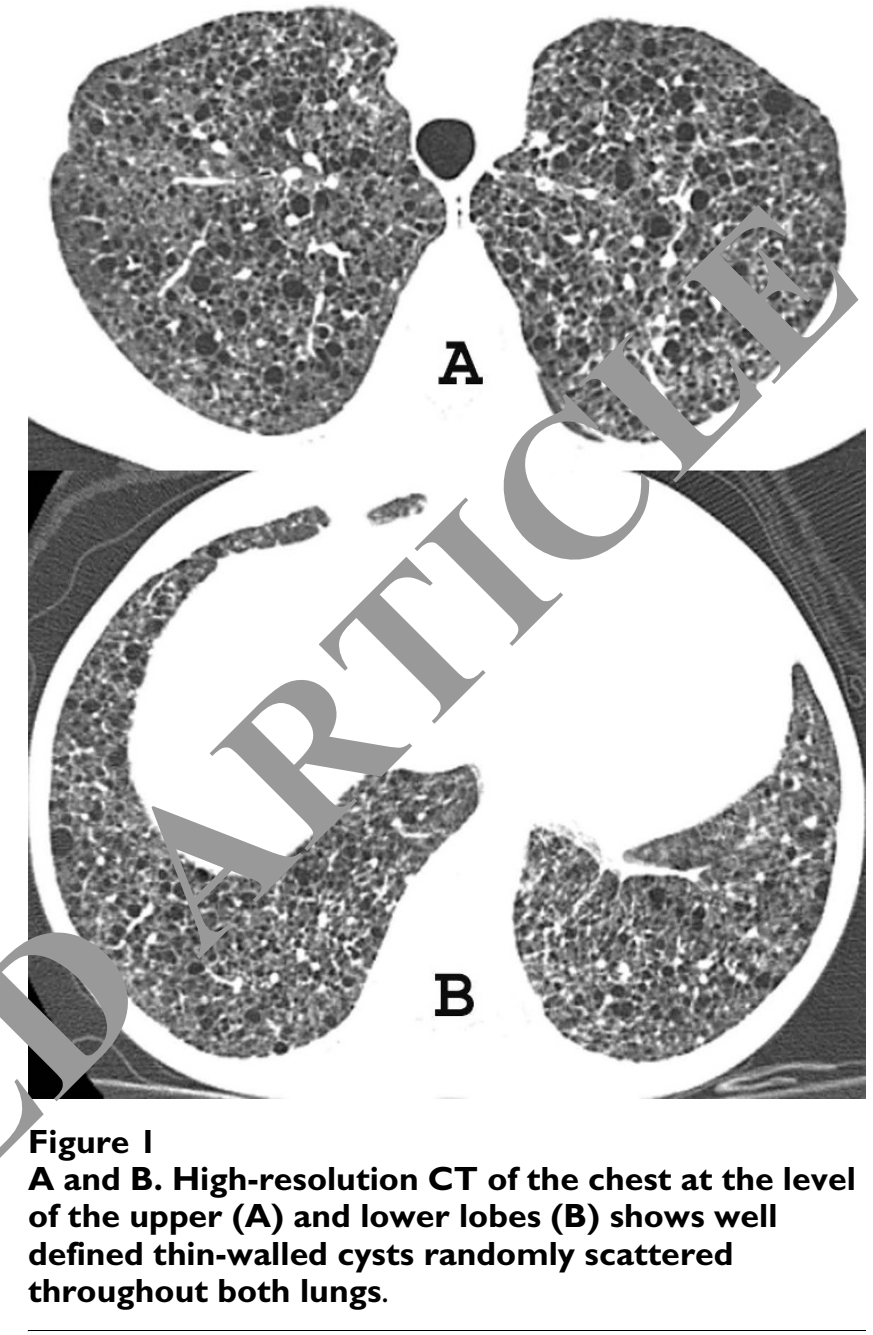

The most frequent cause of death in patients with TS is renal complication [3,5]. Multifocal, bilateral angiomyolipomas are found in about $70-90 \%$ of adult patients [3], and the prevalence increases with age, being less frequent in children $[3,4]$. These lesions are more often prevalent in women, suggesting a hormonal component to the tumor growth [6]. The angiomyolipomas are composed of varying amounts of mature adipose tissue, smooth muscle, and abnormal blood vessels $[3,6]$. The demonstration of intratumoral fat with negative attenuation values at CT is virtually pathognomonic of angiomyolipoma. Thin-section unenhanced CT is essential to visualize the fat content of angiomyolipomas [7]. Progressive enlargement of tumors and hemorrhage into the lesion can result in flank pain, a palpable tender mass and gross or microscopic hematuria, and interfere with renal function [6]. Tumors larger than $4 \mathrm{~cm}$ in diameter have a greater risk of spontaneous or traumatic rupture resulting in hemorrhagic complications [6], which is the most common cause of death in patients with TS [8]. Some patients with TS carry a con- 


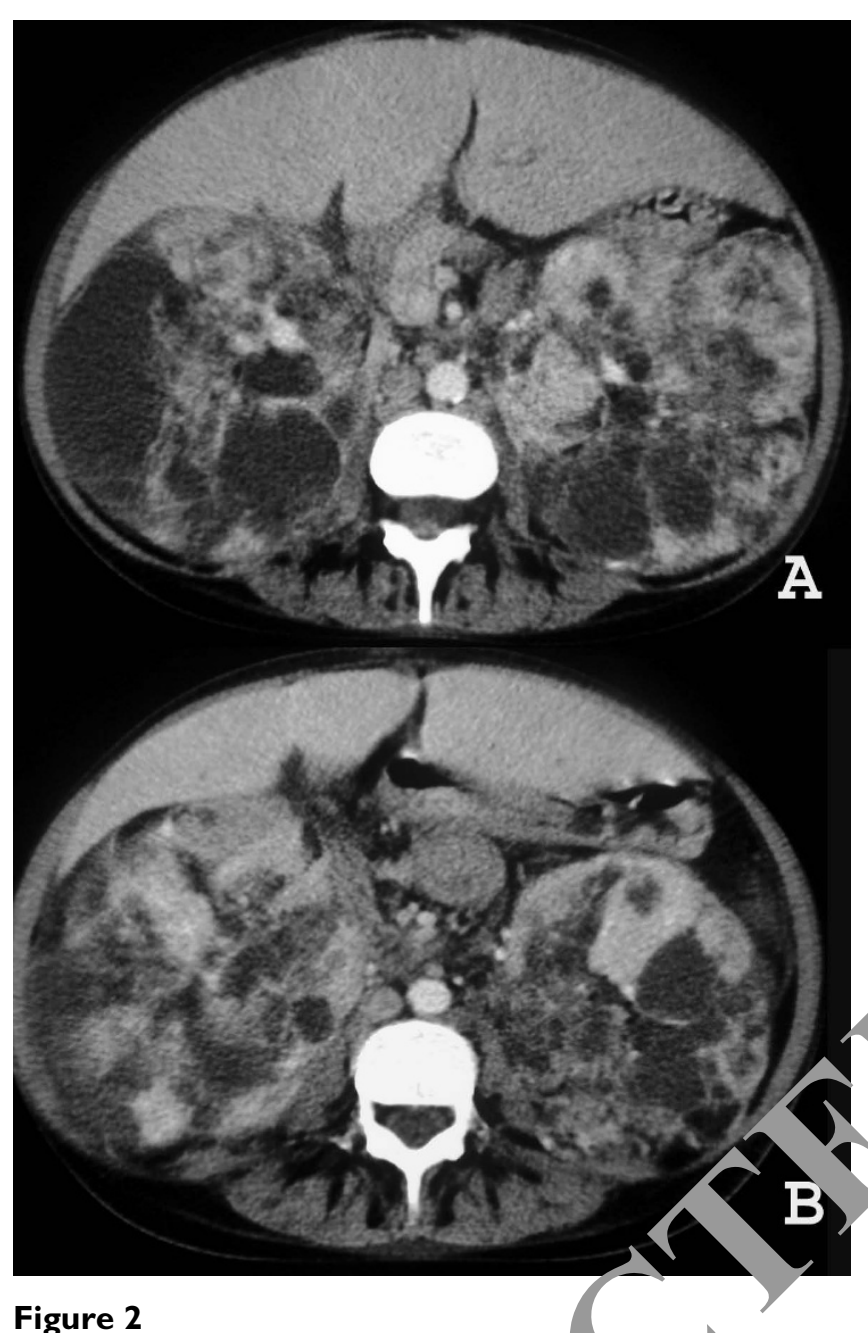

Figure 2

$A$ and B. CT of the upper abdomina egion demonstrates bilateral giant renal masses ca ing predominantly of fat tissue. The de measurement of the hypodense content ranged from $-15 \mathrm{tc}-1, \sigma \mathrm{Ho}$ unsfield units.

tiguous germline 'etion th affects both the TSC2 gene and the adjacent ge polycystic kidney disease type 1 (PKD1), resulting in a polycystic kidney phenotype that leads to $y$ nal insufficiency $[3,4]$. In our patient, the family histo inarcates that she inherited a germline $\mathrm{m}$ ratic In ti.e TSC2 gene. Renal cell carcinoma can occ.

Pulmonary LAM is a rare progressive disease that predominantly affects women of childbearing age. Estrogen is thought to play a role in disease progression since it does not present prior to menarche and only rarely after menopause [9], and is exceptionally rare in men [1,3,8]. LAM probably affects $1-3 \%$ of patients with tuberous sclerosis $[3,5]$. Although some articles report the occurrence of LAM in 1 to $3 \%$ of the patients with TS $[3,5]$, it seems that this incidence is much higher. Recent articles [10-12] report an incidence ranging from 26 to $34 \%$. It is characterized by alveolar smooth-muscle proliferation leading to air trapping, pulmonary hemorrhage and lymphatic extravasation, and cystic destruction of the normal lung parenchyma [3]. Some of the manifestations are shortness of breath, coughing, chest pain, pneumothorar, chylous pleural effusions, hemoptysis, and eventually o ato $\mathrm{y}$ failure, but asymptomatic cases may occur $[1,3,4]$. 1m.onary function tests can show an obstry ive or rest, ctive pattern [1]. Classical CT findings (diffuse, omo,eneous, small thin-walled cysts) and cor patible cal history can be highly suggestive of LAM 5]. It is extremely difficult to treat, and the long-te pr osic is poor with the average duration of survial $m$ the time of diagnosis near to 10 years [1] reatmen onsists of supportive management; horm nal rapy has been tried but without consistent soss $[1$, Sirolimus (rapamycin) is being explore as a other potential treatment, but additional trials wilı necued to assess efficacy and potential side effectc $\lceil 11,13\rfloor$

Renal angi-myolipomas are present in 93\% of patients with tubero $s$-sclerosis-associated pulmonary lymphangiom, natosis [3]. It is important to recognize LAM before nal urgery for angiomyolipoma because of the risk of $s_{\mathrm{I}}$-taneous pneumothorax or other perioperative pulmonary complication $[5,8]$. Pneumothoraces ultimately occur in approximately 60 to $70 \%$ of patients with LAM, and the rate of recurrence is $>70 \%$, the highest among all chronic lung diseases [11].

Finally, it is very important to understand that a patient with TS requires a multidisciplinary clinical staff to receive a complete evaluation of the multisystem complications. In patients with lymphangiomyomatosis, annual pulmonary-function testing may be useful to monitor lung function and provide a measure of disease progression [4]. The monitoring of angiomyolipomas growth, by ultrasonography, CT, or magnetic resonance, is an essential issue in the management of TS [4].

\section{Abbreviations}

TS: tuberous sclerosis; LAM: lymphangiomyomatosis; CT: computed tomography.

\section{Consent}

Written informed consent was obtained from the patient for publication of this case report and accompanying images. A copy of the written consent is available for review by the Editor-in-Chief of this journal. Funding was neither sought nor obtained.

\section{Competing interests}

The authors declare that they have no competing interests. 


\section{Authors' contributions}

FGV conceived the study. BSL, JFC, CA and IGS performed the literature review. FGV, EM, GZ, CMM, AASMDS and ADV edited and coordinated the manuscript. All authors read and approved the final manuscript.

\section{References}

I. Hancock E, Tomkins S, Sampson J, Osborne J: Lymphangioleiomyomatosis and tuberous sclerosis. Respir Med 2002, 96(I):7-13.

2. Choyke PL, Glenn GM, Walther MM, Zbar B, Linehan WM: Hereditary renal cancers. Radiology 2003, 226(I):33-46.

3. Curatolo P, Bombardieri R, Jozwiak S: Tuberous sclerosis. Lancet 2008, 372(9639):657-68.

4. Crino PB, Nathanson KL, Henske EP: The tuberous sclerosis complex. N Engl J Med 2006, 355(I 3): | 345-56.

5. Tuzel E, Kirkali Z, Mungan U, Culer C, Sade M: Giant angiomyolipoma associated with marked pulmonary lesions suggesting lymphangioleiomyomatosis in a patient with tuberous sclerosis. Int Urol Nephrol 2000, 32(2):219-22.

6. Wright T, Sooriakumaran P: Renal angiomyolipoma presenting with massive retroperitoneal haemorrhage due to deranged clotting factors: a case report. Cases J 2008, I (I):2I3

7. Prasad SR, Surabhi VR, Menias CO, Raut AA, Chintapalli KN: Benign renal neoplasms in adults: cross-sectional imaging findings. AJR Am J Roentgenol 2008, 190(I): I58-64.

8. Yoshida S, Hayashi T, Ishii N, Yoshinaga A, Ohno R, Terao T, Watanabe T, Yamada T, Osada $\mathrm{H}$ : Bilateral renal angiomyolipoma coexistent with pulmonary lymphangioleiomyomatosis and tuberous sclerosis. Int Urol Nephrol 2006, 38(3-4):4I3-5.

9. Johnson SR, Tattersfield AE: Clinical experience of lymphangioleiomyomatosis in the UK. Thorax 2000, 55(12): 1052-7.

10. Costello LC, Hartman TE, Ryu JH: High frequency of pulmonary lymphangioleiomyomatosis in women with tuberous sclerosis complex. Mayo Clin Proc 2000, 75(6):59I-4.

II. McCormack FX: Lymphangioleiomyomatosis: a nic.l update. Chest 2008, 133(2):507-16.

12. Moss J, Avila NA, Barnes PM, Litzenberger RA, Bechtle / brooks Hedin CJ, Hunsberger S, Kristof AS: Prevalence and rical char acteristics of lymphangioleiomyomatosis (L, M) vatients with tuberous sclerosis complex. Am J Respir' rit Care, '200I, 164(4):669-7I.

13. Bissler JJ, McCormack FX, Young LR, Elwin JM, Chuck G, Leonard JM, Schmithorst VJ, Laor T, Brody AS, Bean Salisbury , Franz DN: Sirolimus for angiomyolipoma in tuberc cler sis complex or lymphangioleiomyomatosis N Eng J Med 2008, 358(2): $|40-5|$.

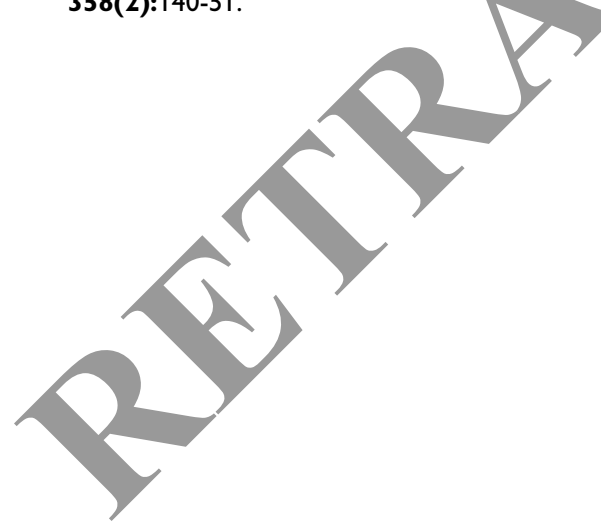

Publish with Bio Med Central and every scientist can read your work free of charge

"BioMed Central will be the most significant development for disseminating the results of biomedical research in our lifetime. "

Sir Paul Nurse, Cancer Research UK

Your research papers will be:

- available free of charge to the entire biomedical community

- peer reviewed and published immediately upon acceptance

- cited in PubMed and archived on PubMed Central

- yours - you keep the copyright 